\title{
A Preferential Trade Area in Northeast Asia Prospects and Problems ${ }^{+}$
}

\author{
Jaleel Ahmad"
}

\begin{abstract}
This article offers an economic analysis of the main policy issues surrounding the proposed preferential trade area (PTA) between Japan, China, and South Korea. This initial assessment is done within the normative framework of customs union theory. Already, intra-regional trade between the three countries constitutes a high proportion of their total trade and is, in fact, cited as one of the main reasons for the PTA. As a consequence, trade creation following the PTA may not result in much new trade. However, it is expected that the PTA would lead to a vigorous growth of intra-industry trade, particularly in manufactured goods and components. Possibilities of trade diversion are real, but not insurmountable if the resulting preference structure is designed with a view to minimize disruption of trade with the rest-of-the-world.
\end{abstract}

Keywords : China, Customs Union Theory, Japan, Korea, Preferential Trade Area (PTA).

\section{INTRODUCTION}

At the end of 2003, there were approximately one hundred active preferential trading areas in different parts of the world, and many others were being contemplated. The World Trade Organization (WTO 2001) estimates that close to 50 per cent of world trade goes through some form of tariff preference. A preferential trading area (PTA), frequently also described, somewhat erroneously, as a free trade area, is a negotiated arrangement in which a group of countries permit imports from each other at preferential (i.e., lower ) tariffs, while maintaining generally higher most favored nation (MFN) tariffs on imports from the rest-of-the-world. The regionalism that has caught the trading world in a frenzy has, however, largely by-passed Asia. In Asia, the largest of the continents with threefourths of the world's population, there is only one fledgling PTA, namely, the ASEAN

Submission Date : 2/11/2005 Acceptance Date : 4/15/2005

*Corresponding Author : Professor of Economics, Department of Economics, Concordia University 1455 de Maisonneuve Boulevard West Montreal QC H3G 1M8, CANADA Email: ahmj@vax2.concordia.ca

${ }^{+}$Most of this article was written during the author's POSCO Fellowship at the East-West Center in Honolulu, Hawaii. Thanks are due to the President of the East-West Center and the Director of Research at the Center for providing research facilities. Thanks are also due to John Gilbert for many helpful suggestions. Huang Wanling and Shen Guo of Concordia University provided capable research assistance. 
free trade agreement (AFTA). This free trade arrangement coexists with a number of other bilateral trade arrangements between countries in and outside the East Asian region. AFTA came into being under the less stringent "enabling" clause of the WTO. Nevertheless, it has made some halting progress in liberalizing trade among its ten member countries, although the volume of intra-AFTA trade remains an insignificant proportion of East Asia's total trade.

It is now being increasingly realized that any regional trading group in East Asia (or indeed elsewhere in Asia) is unlikely to be viable without the active participation of the three "powerhouse" economies of northeast Asia, namely, Japan, China, and South Korea. The combined gross domestic product (GDP) of the three northeast Asian economies is ten times larger than the total GDP of the ten AFTA countries. Their aggregate intraregional trade is close to 60 per cent of their total trade and roughly comparable to intraregional trade of the European Union (EU). The real challenge for formal regional trade arrangements, by all criteria, lies in northeast Asia where a PTA either between the three countries of the region or the one encompassing the ASEAN, dubbed ASEAN + 3, has the prospect of significantly altering the trading landscape in Asia. Also it has the potential to make some difference to the region's trade with the West, although not necessarily negative, as well as to world trade itself. A PTA between the northeast Asian countries has, in fact, been proposed at different times in a variety of policy discussions and is the subject of this article. Although the details of this proposal have yet to be worked out, the broad contours that have emerged are sufficient for a preliminary analysis of its overall policy implications.

In addressing these issues, Section II provides a brief description of the northeast Asian region. Intra-regional trade is the subject matter of Section III. The northeast Asia's trade with the rest-of-the-world is described in Section IV. Section V provides an overview of the framework of analysis. Some salient features and preconditions for regional integration in northeast Asia are presented in Section VI. Possible trade diversion in a northeast Asian PTA is analyzed in Section VII. The prospects and problems arising from the PTA are discussed in Section VIII, while the reaction of the United States is commented upon in Section IX. Section X presents concluding comments.

\section{THE REGION}

The northeast Asian region is at present one of the most dynamic parts of the world economy, largely because of the emergence of China as a major trading entity and as the destination of the bulk of foreign direct investment (FDI). The three northeast Asian countries contain 1.4 billion people (roughly a quarter of the world's population) and in the year 2003 had a combined GDP of US\$6.4 billion at market prices (roughly one-fifth of the world's GDP) and an estimated US\$10.5 billion at Purchasing Power Parity. Being a collection of heterogeneous economies of different sizes, the region has vast disparities in per capita incomes, ranging from a high of US\$32,580 in Japan to a low of $\$ 750$ in China, while Korea at US\$8,150 occupies a middle position. Much more significantly, 
there is also a wide disparity in their resource endowments and structural characteristics, as well as in the stage of development of individual countries. Japan possesses an advanced and a fairly sophisticated technological base and Korea is rapidly catching up, while China's main resource is a vast and well-trained labor force which complements the region's capital and technological resources.

The region has a high stake in world trade. In addition to their substantial trade with each other, the countries in the region trade extensively with the West, in particular, with the United States (US) and the European Union (EU). The region's global (merchandise) exports in the year 2003 amounted to $\$ 1,315$ billion while imports were $\$ 1,205$ billion, both in current prices. The region is in the process of becoming increasingly wealthy, gradually more open to trade and capital movements, and, as a result, more interdependent and cohesive in particular ways.

The recent past has seen a flurry of policy discussions on the desirability of initiating formal regional trading arrangements in the northeast Asian region. These largely academic, and as yet non-official, discussions have decisively shifted the center of gravity toward the three northeast Asian economies. Currently, there are at least twenty- five different proposals for establishing regional trading groups, most of them involving the three northeast economies in one way or the other (Scollay 2001; Gilbert and Scollay 2001; Findlay 2001). Of all these proposals, the prospect of a PTA between Japan, China, and Korea appears the most alluring, although its prototype and methods of realization are far from clear. The focus on northeast Asian countries is understandable given their economic size, but perhaps also because of the pronounced diversity in their resource base and production structures. This diversity signifies a vast array of profitable and hitherto unexploited opportunities for specialization and trading in a complementary and selfreinforcing manner.

The lack of progress to date in moving toward a formal trading area in northeast Asia is due primarily to the past reluctance of Japan and China in forming or joining any regional trading arrangement, in or out of Asia. That reticence seems to be undergoing a change, in no small part due to the emergence of China as a major trading entity and the attraction it provides as a lucrative trading partner to other countries in the region. Current economic difficulties in Japan have also prompted her to seek larger markets elsewhere in Asia. Moreover, northeast Asia is looking beyond its current participation in the Asia Pacific Economic Cooperation (APEC), the venerable inter-governmental group that has some pretensions as a trade-enhancing mechanism. The Asian financial crisis of 1997-98, and the ensuing "contagion" which followed it, was the catalyst that brought to the fore the seeming inability of the APEC to offer either a diagnosis or a solution. Influential policy analysts in the region are now looking beyond APEC-type of "open regionalism" toward more formal, rule-based, cooperation mechanism with northeast Asia as its nucleus, and ultimately to an EU-style economic community which embraces AFTA as well. The proponents believe that the region has considerable economic vitality but lacks a cohesive multilateral mechanism to enhance trade and capital movements, although all major countries in the region are contracting parties to the WTO. It may seem paradoxical 
but a further reason for the lack of progress in moving toward a viable trading group is, in fact, the proliferation of bilateral trade agreements of assorted vintages that have tended to act as more than a minor stumbling block to the emergence of a comprehensive northeast Asian trading region.

\section{INTRA-REGIONAL TRADE IN NORTHEAST ASIA}

Underlying the current activism toward seeking a regional umbrella is the realization that mutual trade between the three northeast economies, despite a fair degree of interdependence, is still short of its full potential. This generalization rests essentially on the observed "overlap" and duplication of similar production activities in individual countries of the region. The latter, in turn, points to a vast potential in intra-industry trade (i.e, trade in similar industries) in a manner not too dissimilar to the one in the EU. In comparative terms, close to 70 per cent of all European trade is intra-EU, and is likely to increase further as the new members from Eastern Europe become functionally integrated. In NAFTA, more than 80 per cent of trade of Canada and Mexico (though not of the United States) is intra-NAFTA. Whether for better or worse, the trading world is getting increasingly polarized into regional blocs. The three northeast Asian economies, which have a large stake in world trade, have an apprehension of being left out on the periphery without a regional group of their own. In the past few years, the United States alone has entered into bilateral trade treaties with six different countries, and is actively pursuing a hemispheric free trade community of some 34 countries in north and south America, the free trade area of the Americas (FTAA). The EU has enlarged itself by admitting 10 new members under its preferential trade umbrella. The "domino" effect that these examples suggest has had a profound bearing on northeast Asia's readiness to contemplate a regional trading mechanism of its own which, in the course of time, may go beyond trade.

While it is true that regional trade liberalization is contrary to multilateralism and has, therefore, provoked dismay in some influential academic quarters (e.g. Bhagwati 1993), its long run implications are not necessarily malign. The OECD (1995) had argued quite early on that regional trade liberalization, far from damaging the cause of multilateralism, may actually provide necessary preconditions for some countries for eventually opening their markets in a larger multilateral framework. This observation is of particular relevance to the developing and emerging market economies of today. The initial dislocations that result from possible trade diversion are quickly dissipated as economic growth in the region increases the two-way trade with rest-of- the- world. The formation of the EU did not lead to a diminution of its world-wide trade, despite a series of minor skirmishes with the U.S. over trade and subsidies in agriculture. Looked at from that perspective, PTAs can be considered "stepping stones" rather than stumbling blocks on the road toward eventual multilateralism.

The reasons why the northeast Asian trade landscape has so far remained free of regional arrangements are deep-rooted. One basic reason, of course, is the enduring preoccupation with exporting to the West, which turned the East Asian region into a 
virtual exporting "machine". The traditional focus of the three northeast Asian economies, as indeed of all of Asia, has been on increasing their exports to the rich countries, particularly the U.S. and the EU, as an avowedly growth-promoting strategy. Indeed, some countries, notably the "Asian tigers", have been quite successful in that strategy and have created an enviable niche in rich country markets for consumer goods. What is surprising, however, is that this all-absorbing focus has not dampened East Asian countries' growing trade relations with each other. Despite sizable trade with Western countries, the intra-regional trade of northeast Asia has been growing steadily in the recent past and is already a high proportion of their total trade. Exports between the three northeast Asian economies amounted to US\$224 billion in 2003, having risen from US $\$ 171$ billion in the previous year. This total represents, on an average, close to 33 per cent of their total overseas shipments in that year (ICSEAD 2004). Another notable feature of this trade is that the bulk of it is in the manufacturing sectors and is intraindustry (i.e. trade within the same industry category). If trade in services were to be included, the percentages would be higher.

Table 1 shows the dimensions of northeast Asian countries' merchandise trade with each other as well as with the United States and the European Union.

Table 1 : Exports and Imports between Northeast Asian Countries with Each Other and the United States and the European Union Expressed as a Percentage of their Total

\begin{tabular}{l|c|c|c}
\hline & Northeast Asia & United States & European Union \\
\hline Japan & 19.7 & 30.4 & 17.3 \\
Exports to & 22.0 & 18.3 & 15.9 \\
Imports from & & & \\
\hline China & 39.1 & 20.4 & 18.3 \\
Exports to & 21.1 & 10.8 & 19.5 \\
Imports from & & & \\
\hline Korea & 29.4 & 20.9 & 15.2 \\
Exports to & 29.2 & 15.9 & 14.8 \\
Imports from & & &
\end{tabular}

Source : International Research Center for the Study of East Asian Development (ICSEAD) (2004) East Asian Economic Perspectives: Recent Trends and Prospects for Major Asian Economies, Kitakyushu, Japan

A major World Bank study of East Asia's intra-regional trade, which includes the intra-regional trade of the three northeast Asian countries ( $\mathrm{Ng}$ and Yeats 2003), concludes that this trade has been growing since mid-1980s at a rate roughly double that of world trade and far higher than the corresponding rates for trade within NAFTA and the EU. The study underscores the fact that the growing "complementarity" between industrial 
structures of the three northeast Asian countries has broadened the scope for intra-industry trade in most manufacturing sectors. It is generally recognized that the presence of significant intra-industry trade is favorable to the viability of regional trade blocs (e.g., Kierzkowski 2001). The complementary character of northeast Asia's trade is accentuated by a significant change in the export structure of China and Korea. China, for instance, has rapidly increased her exports of consumer products, chiefly electronics, to the other two countries, relying on imported inputs from them and its lower processing and assembly costs. Both China and Korea, and to a lesser extent Japan, have rapidly increased their exports to the United States but their intra-regional trade is expanding at a relatively faster rate. At the moment, China is able to export manufacturing products, chiefly electronics, to the northeast Asian region with the collaboration of foreign-owned joint enterprises, but indigenous capacity is rapidly growing.

An account of northeast Asia's growing interdependence in trade would not be complete without highlighting its self-propelling character. The remarkable thing is that this interdependence is the result of spontaneous market forces, without the benefit of any tariff preferences, such as in the EU or in North America. It could perhaps be argued that given that intra-regional trade is steadily increasing on its own momentum, a PTA is unnecessary. On the other hand, it is also clear that any future significant increase in intraregional trade would likely impinge on powerful domestic lobbies, since residual protection, particularly in agriculture and most manufacturing sectors, remains widespread in all three countries. Seen against this backdrop of potential resistance to more liberal trade, PTAs may serve as one possible route to breaking this resistance through mutual "swapping" of preferences. There is also the matter of widespread quota restrictions (QRs) and other non-tariff barriers which probably restrict trade more than do the tariffs. QRs cannot be negotiated away in the same way as tariffs can, but a PTA can attempt to reduce their number and severity through specific "protocols" that deal with non-tariff barriers on the lines that were followed in the Tokyo Rounds under the then GATT. A PTA, by its nature, releases forces that help the industries become more competitive and this competition-enhancing effect not only increases trade but also favorably affects economic growth. A majority of studies following the formation of the European Economic Community (EEC), (the precursor of the EU), estimated a rise in the rate of economic growth in all member countries Nevertheless, a PTA also poses risks to northeast Asia's trade with the West, as we discuss in the following paragraphs.

\section{NORTHEAST ASIA'S TRADE WITH THE REST-OF-THE-WORLD}

Despite growing mutual interdependence, the northeast Asian region remains uniquely dependent on its trade with the rest-of-the-world. This dependence is also shown in Table 1. The three northeast Asian countries have substantial two-way trade with the United States (and its partners in NAFTA) as well as with the EU. Northeast Asia's trade with the West has some unique features that seem noteworthy. First, a part of northeast Asia's intra-regional trade should properly be counted as an integral part of the region's trade with the West. This is because a significant part of the Japanese and Korean exports to 
China, (currently reckoned as part of intra-regional trade), for instance, consists of shipment of components for assembly that are eventually re-exported, after a change in value-added, as final goods to the United States and the European Union. The rapid rise in intra-regional trade in the northeast region does not seem to have diminished the region's dependence on sources of demand outside Asia. Second, Japan's trade with the United States has an important financial counterpart in inter-temporal lending and borrowing, which has been mutually profitable to both. China (including Hong Kong SAR) has recently surpassed Japan as the largest two-way trade partner of the United States. The pattern of inter-temporal trade in goods and assets is likely to be repeated as China replaces Japan as the country with which the United States has the largest trade deficit. It, therefore, seems imperative that the growing integration in the northeast Asian region builds on its close trade links with the rest-of-the-world, rather than at its expense. Despite its enduring character, northeast Asia's trade with the United States has witnessed continuous wrangling, first with Japan and now with China. An emerging PTA should be designed in a manner that avoids exacerbating these trade frictions. An important question in this regard is as to whether a PTA in northeast Asia, and perhaps its extension to ASEAN +3 in the future, would significantly alter the parameters of existing trade with the West.

\section{A FRAMEWORK OF ANALYSIS}

Contrary to some perceptions, PTAs do not bring unmitigated benefits. Nor are they a recipe for disaster. The benefits and costs of a PTA, like all "second best" propositions, occur simultaneously and have to be clearly identified. The generally-accepted customs union theory provides a natural framework for assessing the economic costs and benefits of a PTA. A clear benefit is the "trade creation" among partner countries that results from tariff preferences that do not apply to non-members. This increase in trade arises essentially because competing production in broadly similar products in each of the bloc countries is either eliminated or reduced, as each country tends to specialize in the production of goods in which it has comparative advantage vis-a-vis other countries in the bloc. As a result, a part of duplicate production in each country is eliminated and is replaced by mutual trade. Trade creation benefits all partner countries since it replaces uneconomic domestic production in each. A by-product of the "swapping" of trade concessions between a group of countries is the gain in economies of scale, where each country tends to produce a smaller range of goods but produces larger quantities of the goods that it does produce. Since trade creation is a net addition to world trade, there is an increase in overall welfare. The main burden of adjustment falls on inefficient domestic production in lines where a partner country offers lower costs. Thus, a PTA has clear efficiency and pro-competitive effects and is inimical to the development of domestic monopolies.

The economic dislocations and the costs arising from a PTA can often be quite substantial, and are spread over a larger number of stakeholders, viz., the member countries of the PTA in question, the non-member trading partners, as well as the world 
trading system at large. Preferences among member countries can give rise to "trade diversion", in so far as member countries substitute their lower-priced imports from the rest-of-the-world with generally higher-cost imports from each other. The imports from each other appear artificially cheaper because they are not subject to tariffs, while imports from elsewhere remain tariff-ridden. There is a fiscal loss as well, as the intra-bloc goods replace goods from the rest- of- the- world on which governments used to collect revenue. Trade diversion has been identified by economists as a loss in "terms-of-trade", since lower-cost imports from elsewhere in the world are replaced by higher-cost imports from partner countries. Trade diversion also implies losses for non-member trading partners as they lose market shares to intra-bloc countries merely because preferences have made the latter's goods artificially cheaper.

The customs union theory makes it clear that a trade-diverting PTA can, nonetheless, improve welfare, since consumers in the bloc pay lower prices for tariff-free goods from partner countries, as long as trade diversion is not the dominant effect of a PTA. In other words, trade liberalization even preferentially confers benefits to the economy in question. In addition, customs union theory highlights a variety of "dynamic" gains from a PTA, such as a (possible) increase in the rate of growth of GDP in member countries and a potential improvement in terms-of-trade of the bloc vis-a-vis other trading blocs. By their very nature, the dynamic gains are difficult to locate precisely and even more difficult to estimate. In some cases, the dynamic effects may be so overwhelming that they dominate the entire calculus of costs and benefits. Again, the experience of the EEC in Europe is a case in point. The estimated gains from trade creation were negligible compared to the ones forecast for dynamic gains, which turned the balance in favor of the original community of the Six countries.

One reason for the proliferation of PTAs is that they can bring considerable benefits to developing and transition economies in integrating them into the mainstream of the world trading system. The classic example of this initiation is that of Mexico which is gradually emerging as a viable trading entity after its successful entry in NAFTA. Similarly, a great part of the appeal for the East European countries to join the EU has been the leverage that the EU membership provides to countries that have been on the sidelines of world trade for close to half a century. It is true that this sort of initiation is not particularly relevant to countries like Japan, China, and Korea which are already major players in world trade. In fact, they stand to lose from an inward-looking policy if the PTA results in excessive trade diversion.

\section{REGIONAL INTEGRATION IN NORTHEAST ASIA}

The process of regional integration presupposes the existence of a number of economic preconditions, namely, a high degree of openness among the region's main economies, highly interdependent and complementary economic ties among them, and a high level of involvement with trade in the international context. Northeast Asia meets all these requirements. These preconditions underscore the likelihood, though not a guarantee, of 
favorable outcomes in a future northeast Asian PTA. It is too early to estimate the potential magnitude of trade creation and trade diversion resulting from the northeast Asian PTA since no credible estimates exist. The true extent of trade creation and trade diversion can be estimated only after an agreement on the tariff structure of the PTA has been reached. But, given the already substantial intra- regional trade between the three countries, it is possible that the post-PTA gains in mutual trade may not be spectacular. The outcome may be analogous to that in NAFTA where trade gains at the end of ten years of its existence have been rather modest. But even a modest increase in mutual trade may mean large benefits in terms of the efficiency of resource use and future growth. One can, for instance, foresee a significant "upgrading" in labor-intensive sectors in China which would be freed of tariff barriers in the other two countries. Similarly, there may be an increase in trade in services, such as banking, insurance, and transportation, as they are certain to be included in the PTA.

Much more significantly, all available data point to a fairly vigorous expansion of intra-industry trade ( i.e., trade in "differentiated" products within the same industry category). The average share of growth in intra-industry trade in the growth of total trade in the East Asian region rose from 42.5 per cent in 1986-90 to 75 per cent in 1996-2000, as estimated by the IMF (Zebregs 2004). The increase in intra-industry trade is a reflection of greater vertical specialization, which implies higher volumes of trade in intermediate goods (Ng and Yeats 1999). Generally, gains in intra-industry trade are considered more significant because it leads firms to specialize in narrower lines of production at higher scales of output and higher productivity (see, for example, Kierzkowski 2001). Such intra-industry specialization leads to an increase in the "variety" and the quality of products available to consumers, without a massive reallocation of resources. The experience of industrial restructuring in the European Economic Community (now the EU) following the establishment of a PTA ( also a customs union) may be a useful reminder. The elimination of intra-European tariffs did not lead to the demise of automobile industry in any of the countries, since each country had its own automobile industry. Instead, each country specialized in the production of a particular variety of automobiles that began to be freely traded a fact that led to a rationalization of automobile production throughout the continent. The prospects of intra-industry specialization and trade are quite sanguine in the northeast Asian region, since Japan and Korea, rapidly followed by China, have large industrial sectors which produce broadly similar goods.

\section{TRADE DIVERSION}

The prospects of trade diversion following the northeast Asian PTA do appear real but no insurmountable. Whatever the magnitude of resulting trade diversion, it is likely to impact primarily on the region's trade with the United States and the EU. Trade diversion losses may increase in intensity if followed by retaliation on the part of trading partners. PTAs are routinely viewed by non-member trade partners as an act of exclusion from the protected domestic markets in the bloc. If trade diversion begins to have an adverse 
impact on domestic producers in the U.S. and the EU, it may lead to a protection backlash and retaliation. A PTA in northeast Asia is particularly likely to be viewed as inimical to producer interests abroad as they perceive a loss of market shares in the large, lucrative, and rapidly growing markets in Asia. The northeast Asian region has benefited from an open trading system and its interests would be better served by avoiding trade conflicts.

There is some concern that recent PTAs in different parts of the world have diverted more trade than created (Yeats 1998; Preusse 2001; Adams, Dee, Gali, and McGuire 2003). The most damaging evidence comes from the MERCUSOR where almost all increase in trade is estimated to be due to trade diversion (Yeats 1998). Even the more liberal PTAs have failed to create significant additional trade among members. These results appear to be more negative, on the whole, than those of earlier studies. The major source of trade diversion in PTAs has been traced to "rules of origin", often characterized as "residual havens of protection", but are nevertheless considered necessary to safeguard the preferential nature of the PTAs. Rules of origin are designed to discourage imports of components and raw materials from outside the area and encourage their production in the PTA. These rules impose cascading distortions of unknown magnitude as their effects on costs and prices permeate the entire production chain. Proper accounting for the protective effects of "rules of origin" in more recent studies has tended to raise the estimates of trade diversion. "Rules of origin" can, of course, be dispensed with in a customs union with a common external tariff which provides equal protection to all producers.

\section{DILEMMA OR AN OPPORTUNITY?}

The proposed PTA in northeast Asia, accordingly, faces an existential dilemma. How to increase the prospects of trade creation and the ensuing gains in efficiency and welfare and simultaneously keep the threat of trade diversion low? The resolution of this dilemma depends uniquely on the design of the PTA and the emerging structure of preferences. The prospects of trade creation can be enhanced by enlarging the "domain" of the PTA by extending its product coverage. In other words, the PTA should include substantially all trade between partner countries, as stipulated in Article 24 of the WTO, and not permit exclusion of sectors and industries because of pressure from vested interests. Nevertheless, the inclusion of some sectors may increase the prospect of trade diversion. Gilbert and Scollay(2001), for instance, estimate that net welfare gains from a KoreaJapan agreement is in fact lower for the participants if agriculture is included because of a significant potential for trade diversion. However, agriculture has given rise to contentious issues in other trading blocs. Witness the difficulties arising from the Common Agricultural Policy (CAP) of the EU both in Europe as well as with trading partners such as the U.S. and Australia. But there does not seem to be enough justification for withholding regional trade liberalization in other sectors just because the inclusion of agriculture causes problems. There are sometimes ad hoc solutions to problems in agriculture. A case in point is the recent agreement in South Korea to provide to the U.S. and 8 other countries greater access to the domestic market for rice in exchange for tariffwaivers. There is always the danger that PTA countries may resort to using so-called trade 
"remedies" - safeguards, antidumping actions, and countervailing measures - as backdoor protection. However, other things being equal, the larger the "domain" of the PTA, the larger the gains from expected trade creation.

The probable effects of trade diversion, by contrast, remain a major source of uncertainty. Trade diversion uniquely depends on the structure of preferences that emerges after negotiations. Accordingly, the worst features of trade diversion can be eliminated or greatly reduced by innovations in the design of the post-PTA tariff structure. The postPTA tariff structure can, in principle, be designed on the lines of the Kemp-Wan (1976) theorem to ensure that the welfare of non-member trading partners does not fall any lower than it was before the PTA. In practice, this means that preferential tariffs are kept to the minimum necessary to provide leverage for intra-regional trade, and, at the same time, are not unduly high to cut out significant proportions of trade with non-members. An even simpler strategy is to gradually lower the tariff bias against non-members at the same time as tariffs are reduced on intra-regional trade. As tariffs are lowered on trade with nonmembers while some preferential margins are preserved for trade with members the outcome in the long run may not be too dissimilar from the one under multilateral liberalization. Thus, overwhelming trade diversion is not a necessary outcome in a northeast Asian PTA.

\section{REACTION FROM THE UNITED STATES}

A major question on everyone's mind is as to how the United States would view the emergence of a northeast Asian PTA, since it has a substantial stake in trade with Asia. The United States has opposed some similar attempts in the past, most notably the illfated proposal for an East Asian Economic Group (EAEG) in the 1990s. Initially, Japan was quite enthusiastic about forming this group but withdrew its support when it became clear that the United States would oppose it. Similarly, a Japan-led initiative for an East Asian Monetary Fund did not get off the ground because of lack of support from the United States. But times have changed. The U.S. has de facto embraced the principle of "walking on two legs", that is by pursuing trade liberalization multilaterally at the WTO and at the same time in regional trade groups, such as the NAFTA and a host of bilateral initiatives with countries as far-flung as Australia. It would look hollow if the U.S. were to oppose a similar initiative for a PTA in northeast Asia. Indeed, the U.S. trade policy may find it easier to deal with a more cohesive body such as the northeast Asian PTA than to wrangle trade concessions from three powerful trading partners. In fact, it seems more than likely that the U.S. trade with the northeast Asian region would actually increase as the northeast Asian economies become richer and demand more American goods. Given these considerations, opposition from the U.S. to a northeast Asian PTA is not a foregone conclusion. In all likelihood, the U.S. would remain neutral, as it has been in all recent episodes of regional trade liberalization. 


\section{CONCLUSIONS}

PTAs in the contemporary world are not only about mutual trade in goods and services. They increasingly encompass a wide range of non-trade issues, such as cross-border movement of capital and firms, intellectual property rights, environment and labor issues, government procurement, competition policy, and movement of persons. The role of foreign direct investment (FDI) is particularly noteworthy. Attracting investment from within NAFTA as well as from outside, for example, was the prime reason for Mexico to enter NAFTA, and the U.S. willingness to welcome it. A very large part of recent foreign investment in Eastern Europe (particularly in Poland and Czech Republic) has been in anticipation of the EU membership. Capital movements in the contemporary world have taken a decidedly regional character. They are, in fact, one prominent motivation behind the recent proliferation of PTAs. A major appeal of forming and joining PTAs is that member countries become attractive sites for the location of FDI, either through new investments or through mergers and acquisitions. The flow of capital, however, is unlikely to be a major drawing card for the northeast Asian PTA. The northeast Asian region is already flush with foreign investment. China alone last year became the largest recipient of FDI, attracting US\$53 billion. However, the direction and volume of future investment flows can still be affected depending upon whether a PTA is in force.

A PTA can also sponsor other forms of cooperation in the northeast Asian region, such as a customs union with a common external tariff, a monetary union (which is already being discussed), and a common energy and security policy. Above all, it can foster greater mutual understanding and cohesion to a region that embraces three great civilizations but lacks a proper understanding of each other. 


\section{REFERENCES}

Adams, R, Dee, P., Gali, J. and McGuire, G. (2003), “The Trade and Investment Effects of Preferential Trading Arrangements: Old and New Evidence," Productivity Commission Staff Working Paper, No. 7, May, Melbourne and Canberra. http://www.pc.gov.au/research/swp/tiepta/index.html

Bhagwati, J.N. (1993), "Regionalism and Multilateralism: An Overview," in J. De Melo and A. Panagariya (Editors) New Dimensions in Regional Integration, Cambridge University Press, New York.: 22-51.

Findlay, C. (2001), “Old Issues in New Regionalism,” Technical Report Pacific Economic Papers No.311, APSEG [Asia Pacific School of Economics and Government], The Australian National University, Canberra. http://eprints.anu.edu.au/archive/00002438/

Gilbert, J.P. and Scollay, R. (2001), New Regional Trading Arrangements in the Asia Pacific?, Institute for International Economics, Washington, D.C.

International Center for the Study of East Asian Economic Development (ICSEAD) (2004), "Recent Trends and Prospects for Major Asian Economies," East Asian Economic Perspectives, 15 (Special Issue), Kitakyushu, Japan.

Kemp, M.C. and Wan H. (1976), "An Elementary Proposition Concerning the Formation of Customs Unions," Journal of International Economics, 6, 95-97.

Kierzkowski, H. (2001), "Joining the Global Economy: Experience and Prospects of the Transition Economies" in S. Arndt and H. Kierzkowsky (eds) Fragmentation: New Production Patterns in the Global Economy, Oxford University Press, Oxford.

Ng, F. and Yeats, A. (1999), "Production Sharing in East Asia: Who Does What for Whom and Why", Policy Research Working Paper Series, 2197, The World Bank, Washington, D.C.

http://econ.worldbank.org/docs/921.pdf

Ng, F.and Yeats, A. (2003), "Major Trade Trends in East Asia, What Are Their Implications for Regional Cooperation and Growth?," Policy Research Working Paper Series 3084, The World Bank, Washington, D.C.

http://econ.worldbank.org/files/27878_wps3084.pdf

Organization for Economic Cooperation and Development (OECD) (1995) Regional Integration and the Multilateral Trading System: Synergy and Divergence, February, OECD, Paris.

Preusse, H. (2001), "Mercosur - Another Failed Move Towards Regional Integration," 
The World Economy, 24, 7: 911-931.

Scollay, R. (2001), "New Regional Trading Arrangements in the Asia-Pacific Region," Unpublished paper presented at the APEC (Asia-Pacific Economic Cooperation) ASC (Study Center) Consortium Conference, Tianjin Economic Technological Development Area (TEDA), May, China

World Trade Organization (WTO) (2001), "Regional Trade Arrangements Notified to the GATT/WTO and in Force," World Trade Organization, Geneva.

http://www.wto.org/english/tratop_e/region_e/region_e.htm

Yeats, A.J. (1998), "Does Mercosur's Trade Performance Raise Concerns about the Effects of Regional Trade Arrangements," World Bank Economic Review, 12 (1): 128.

Zebregs, H. (2004), "Intraregional Trade in Emerging Asia," Policy Discussion Paper, No. 04/1, International Monetary Fund, Washington, D.C. 